\title{
Some Aspects of the Distribution of Fusarium on Cereals of Russia
}

\author{
M. I. KISELEVA*, A. V. OVSYANKINA, T. M. KOLOMIETS, \\ N. S. ZHEMCHUZHINA and A. P. GLINUSHKIN \\ All-Russian Research Institute of Phytopathology of Federal Agency of Scientific Organizations of Russia, \\ Moscow region, Institute str. 5, Bolshie Vyazemy, 143050 Russia
}

(Received: 19 May 2016; 4 June 2016)

\begin{abstract}
Since 1995 the pathogens of genus Fusarium causing Root Rot, Snow Mold, Fusarium Head Blight of grain crops have been monitored in the Volga-Vyatka, Central, Central Chernozem and North Caucasian regions of the Russian Federation and in there were identified 15 Fusarium spp.: F. culmorum, F. heterosporum, F. sporotrichioides, F. oxysporum, F. nivale, F. graminearum, F. avenaceum, F. gibbosum, F. sambucinum, F. moniliforme, F. semitectum, F. poae, F. lateritium, F. solani, F. redolens. The high uniformity of Fusarium spp. has been revealed for the regions due to the susceptibility of crops to the soil-inhabiting micromycetes. Consistent long-term monitoring of the dynamics and frequency of occurrence of Fusarium spp. in a wide range of climatic areas has made it possible to characterize the state of the species of fungi in the regions and also to study their intraspecific and interspecific variability in toxicity and pathogenicity depended on biotic and abiotic factors. The prevalence of Fusarium spp. in the mycobiota has been determined by their plasticity and viability in the soil, on the weed roots and in the stubble of many crops and high competitive ability expressed pathogenicity and toxicity.
\end{abstract}

Keywords: cereals, fungal diseases, Fusarium spp., pathogenicity, toxicity, intraspecific and interspecific variability.

The distribution of facultative phytopathogenic fungi of the genus Fusarium in cereals has created threat to increase infectious background for the soil and the grain. The agents causing Root Rot, Snow Mold and Fusarium Head Blight have belonged to parasitic low specialized fungi founded in all regions of grain cultivation (Bilai, 1977; Gagkaeva et al., 2011). Pathogenicity of the Fusarium fungi has been determined due to their ability to produce hydrolytic enzymes and toxins (Pomeranz et al., 1990; Parry et al., 1995). For example, $F$. graminearum, $F$. tricinctum isolates have generated zearalenone, $F$. moniliforme and $F$ proliferatum - fumonisin, $F$ moniliforme, $F$. acuminatum, $F$. avenaceum, F. oxysporum - moniliformin (Ivanov et al., 2013). The mechanism of toxic action of fungi has been the ability to inhibit protein synthesis of living beings. Mycotoxins have been characterized by exhibiting strong anabolic and estrogenic effects (Toropova et al., 2013). Identified different levels of Fusarium toxicity have depended on the host plant and the cultivation conditions (Shakhnazarova et al., 2004).

\footnotetext{
* Corresponding author; e-mail: kiseleva@vniif.ru
} 
The study of the environmental effect on mycocenosis above-ground and underground parts of spring wheat have shown the annual dominance of Fusarium spp. along with the genera Bipolaris sp., Alternaria sp., Penicillium spp., Cladosporium spp., Aspergillus spp. The genus Fusarium has been characterized by significant species diversity and confinement to certain types of soils, sensitivity to fungicides (Burgess and Griffin, 1967).

The main factors of pathogen transmission have been able to contain the infection in soil, stubble and seed infected by the fungus.

Fungi of the genus Fusarium are capable of long saprotrophitic development in the soil. So the mycelium of $F$. culmorum has remained viable long time and has developed in the soil colonizing plant residues for the period to infect the plant (Tuterev, 2005; Kirichenko and Toropova, 2007).

The intensity of development and the prevalence of Fusarium spp. have depended on weather of vegetation period, genotypic and field resistance of grain cultivars, agronomical and technological methods of cultivation. Seeds have been transmitted to $60 \%$ of plant diseases (Toropova et al., 2011). Contamination of spring wheat seeds of Fusarium spp. is $3-5 \%$ annually. Infected seeds have got low germination rate, their viability has reduced (Toropova et al., 2010; Toropova et al., 2012).

The use of technology while minimizing the mechanical impact on soil and short crop rotations has led to expressive dynamics of root rot in agriculture of Russia (Wagacha and Muthomi, 2007; Toropova et al., 2015). Thus there were noted the highly toxic and invasive species of F. sporotrichioides (Sherb.), F. poae (Peck) Wr., F. avenaceum (Fr.) Sacc., F. equiseti (Corda) Sacc., F. oxysporum (Schlecht) in the forest-steppe of Western Siberia (Grishanova, 2014). Species of F. culmorum has dominated in colder areas of North and Central Russia. The Fusarium Head Blight is most active in Krasnodar territory, Kaliningrad region, Northern Russia (Leningrad region) and partly the Central Chernozem region - Belgorod, Vladimir, Ryazan, Tula and other areas favorable for cultivation of cereals. Contamination of grain by Fusarium spp. has made up around $5 \%$ in the Central and North-Western districts. A sharp increase in the infection intensity of seeds (up to 7\%) in southern regions of the country (Krasnodar territory, Stavropol territory and the Rostov region) has contributed to epidemics of Fusarium in 2014 (Popov, 2015).

The species composition of the genus Fusarium may change depending on weather and cultural practices in the crop cultivation. The disease progress on the seeds has been noticed in wet years due to the hydrolytic breakdown of the carbohydrates has produced a favorable nutrition environment and reproduction of fungi (Toropova et al., 2010). Fusarium Head Blight is the disease typical for warm humid climate areas. So F. graminearum has caused the most famous epidemics in the southern part of Russia. The Fusarium spp. has been ecologically flexible and they are common for all grain-producing regions of Russia including the regions with insufficient moistening during the vegetation (Gagkaeva et al., 2011).

The goal of the work was the collation of data on species composition and frequency of occurrence of fungi of the genus Fusarium as well as to evaluate pathogenic and phytotoxic properties of strains of Fusarium spp. for the selection of the state collection for keeping and use in breeding studies as infectious material. 


\section{Materials and Methods}

The infected material was sampled from plants of spring and winter wheat, spring barley and winter rye collected in 1995-2014 on the territory of the Volga-Vyatka, Central, Central Chernozem and North Caucasian regions of the Russian Federation. Mycological analysis of diseased samples of seeds and roots was carried out on a nutrient medium of čapek and $2 \%$ potato-dextrose agar according to the standard methods in a 5-10 replications (Dudka, 1982).

Isolates of Fusarium spp. were specified according to the morphology of colonies and conidia (Bilai, 1988). Phytopathological analysis of seed was conducted by the method of roll-examination by the V. A. Chulkina (Chulkina et al., 2009).

Pathogenicity and toxicity of Fusarium spp. isolates were studied in 2014-2015 in the ARRIP department using the method of biosample on seeds (Parfenova and Alekseeva, 1995). Pathogenicity of spore suspensions was determined as following. Petri dishes with potato-glucose agar were sown with pieces of mycelium using microbiological loop. Each strain was grown in 5 Petri dishes. Petri dishes were incubated in thermostat at $25^{\circ} \mathrm{C}$ for 2 weeks. After incubation $10 \mathrm{ml}$ of sterile tap water were added to each Petri dish, mycelium was washed off the agar surface with a scalpel and transferred to $250 \mathrm{ml}$ Erlenmeyer flasks with a pipette. The flasks were shaken for $5 \mathrm{~min}$ and the spore suspension was filtered from the rest of mycelium through 2 layers of cloth and the volume was brought to $50 \mathrm{ml}$. Amount of spores in $1 \mathrm{ml}$ of suspension was calculated in Garyaev camera. Ten seeds were placed in sterile Petri dishes on sterile filter paper and $6 \mathrm{ml}$ of spore suspension were added into each dish. Tap water was used in control variants. Petri dishes with seeds were incubated for 5 days at room temperature and natural illumination. Further degree of seed germination was determined and length of coleoptiles and roots was measured. As the object-tester to determine the pathogenicity and toxicity of the Fusarium strains were used seedlings of the wheat cultivar Mironovskaya 808 susceptible to Root Rot pathogens.

The seeds of the wheat-tester were germinated in suspension of conidia $\left(10^{6}\right)$ and the filtrate of culture fluid to detect the pathogenicity and toxicity of the fungus strains. Strains of pathogens were differentiated into four groups by the signs: non-pathogenic/non-toxic (inhibition of plant growth at $0-30 \%$ ), slightly pathogenic/slightly toxic (inhibition at $31-50 \%$ ), moderately pathogenic/moderately toxic (inhibition at 51-70\%), pathogenic/ toxic (inhibition of more than 70\%). Pathogenicity and toxicity of fungus isolates were evaluated by the degree of inhibition of seed germination, growth of coleoptiles and the roots. The data of seed germination and growth of seedlings in water was used as a check.

All experiments were performed in three replicates. Statistical processing of results was performed using a modified program developed in the environment of Windows 98based, Microsoft Excel (Sorokin, 2009).

\section{Results and Discussion}

Since 1995 in All-Russian Research Institute of Phytopathology there the pathogens of genus Fusarium causing Root Rot, Snow Mold, Fusarium Head Blight of grain crops have been monitored in the Volga-Vyatka, Central, Central Chernozem and North 
Caucasian regions of the Russian Federation. There were identified 15 Fusarium spp.: F. culmorum, F. heterosporum (Gibberella gordonii), F. sporotrichioides, F. oxysporum, $F$. nivale (Monographella nivalis), F. graminearum (G. zeae), F. avenaceum (G. avenacea), F. gibbosum (G. intricans), F. sambucinum (G. pulicaris), F. moniliforme (G. moniliformis), F. semitectum (F. incarnatum), F. poae, F. lateritium (G. baccata), F. solani (Nectria haematococca), F. redolens.

The frequency of occurrence of Fusarium spp. has varied depending on climate of cultivation areas of grain crops, and weather conditions of the year, the localization of the pathogen on plants, previous crop, etc. However in the areas of cereal cropping the composition of Fusarium fungi was represented by the same species among which in the mycorrhiza of barley, wheat and rye there were most often identified the following 10 species: F. culmorum, F. oxysporum, F. heterosporum, F. sporotrichioides, F. nivale, F. avenaceum, $F$. sambucinum, F. gibbosum, F. poae, F. solani (Table 1). The incidence of F. culmorum, $F$. heterosporum, $F$. sporotrichioides, $F$. oxysporum together has accounted for more than $50 \%$ of all identified isolates of the fungi. Species such as F. lateritium, F. semitectum, F. poae, F. solani, F. redolens were met single.

\section{Table 1}

The mean frequency of occurrence of Fusarium spp. isolates in the major areas of wheat cultivation for the period 1995-2014, \%

\begin{tabular}{lcccc}
\hline \multirow{2}{*}{ Species } & \multicolumn{4}{c}{ Regions of cereal cultivation } \\
\cline { 2 - 5 } & Volga-Vyatka & Central & Central Chernozem & North Caucasus \\
\hline F. culmorum & 22.7 & 26.6 & 21.8 & 15.6 \\
F. heterosporum & 4.5 & 6.4 & 11.9 & 15.0 \\
F. sporotrichioides & 14.3 & 18.3 & 20.9 & 11.9 \\
F. oxysporum & 26.6 & 19.8 & 5.1 & 7.7 \\
F. avenaceum & 5.8 & 2.7 & 3.4 & 5.8 \\
F. moniliforme & 2.6 & 2.2 & 5.1 & 6.1 \\
F. graminearum & 0 & 1.2 & 17.5 & 26.4 \\
F. poae & 0 & 0.6 & 4.3 & 3.7 \\
F. solani & 0 & 1.4 & 3.4 & 1.5 \\
F. semitectum & 0 & 0.7 & 2.5 & 3.7 \\
F. sambucinum & 11.7 & 6.3 & & 1.5 \\
F. gibbosum & & 3.6 & & 0.9 \\
F. nivale & 11.7 & 8.2 & 3.8 & \\
F. lateritium & & 0.3 & & \\
F. redolens & & 1.4 & & \\
Total number of isolates & 154 & 671 & 234 & $(100 \%)$ \\
\hline
\end{tabular}


The isolates of $F$. graminearum were found more often in the southern regions of wheat cultivation. The frequency of occurrence of $F$. graminearum isolates in Central region has amounted to $1.2 \%$ and in the Central Chernozem and North Caucasus to $17.5 \%$ and $26.4 \%$, respectively. Also, on the wheat there were noted the positive dynamics from North to South for F. heterosporum: from $4.5 \%$ in the Volga-Vyatka to $15.0 \%$ in the North Caucasus.

The incidence of $F$. nivale isolates from the Volga-Vyatka and Central regions in 2012 on rye (21.7-32.4\%) was higher than on barley and wheat (from 10.7 to $14.7 \%$ ) possibly due to the rye biology and habit (Table 2). Usually the winter rye has been cultivated in the northern parts of the country characterized long periods of moisture in autumn and spring, frequent thaws in winter provoking the $F$. nivale progress and as a result the roots and lower nodes of the stems of the crop have damaged.

It is known that the Fusarium infection accumulates in the soil and crop residues. There in the soil the fungus infects the primary roots of germinating seeds. During the growing season the infection (spores and hyphae) is transmitted by layers of plant colo-

Table 2

The incidence of $F$. nivale isolates on the roots of wheat, barley and rye in the Volga-Vyatka and Central regions in 2012,\%

\begin{tabular}{lccc}
\hline Origin & Wheat & Rye & Barley \\
\hline Volga-Vyatka region & 14.7 & 21.7 & 8.1 \\
Central region & 11.4 & 32.4 & 10.7 \\
\hline
\end{tabular}

Table 3

The incidence of Fusarium spp. - the causative agents of Root Rot and Fusarium Head Blight of barley in the Central region in 2012-2014, \%

\begin{tabular}{|c|c|c|c|c|c|c|c|c|}
\hline \multirow{2}{*}{ Species } & \multicolumn{2}{|c|}{2012} & \multicolumn{2}{|c|}{2013} & \multicolumn{2}{|c|}{2014} & \multicolumn{2}{|c|}{ Mean } \\
\hline & roots & ears & roots & ears & roots & ears & roots & ears \\
\hline F. culmorum & 21.4 & 10.3 & 22.0 & 0 & 22.9 & 0 & 22.0 & 3.9 \\
\hline F. nivale & 10.7 & 0 & 19.5 & 0 & 17.2 & 0 & 15.1 & 0 \\
\hline F. sambucinum & 14.3 & 0 & 7.3 & 0 & 0 & 0 & 8.3 & 0 \\
\hline F. gibbosum & 3.8 & 0 & 0 & 0 & 8.6 & 0 & 3.8 & 0 \\
\hline F. heterosporum & 19.6 & 0 & 19.5 & 0 & 14.3 & 0 & 16.7 & 0 \\
\hline F. solani & 5.4 & 0 & 2.4 & 0 & 5.7 & 0 & 4.5 & 0 \\
\hline F. sporotrichioides & 8.9 & 41.4 & 14.6 & 27.3 & 14.3 & 76.0 & 12.1 & 48.7 \\
\hline F. oxysporum & 12.5 & 27.6 & 9.8 & 36.4 & 17.1 & 12.0 & 12.9 & 25.0 \\
\hline F. poae & 0 & 3.4 & 2.4 & 9.1 & 0 & 0 & 0.8 & 3.9 \\
\hline F. avenaceum & 3.8 & 17.2 & 2.4 & 18.2 & 0 & 12.0 & 2.3 & 15.8 \\
\hline F. semitectum & 0 & 0 & 0 & 9.1 & 0 & 0 & 0 & 2.6 \\
\hline Total isolates & 56 & 29 & 41 & 22 & 35 & 25 & 132 & 76 \\
\hline
\end{tabular}


nizing the leaves, spike and grains. The place of localization of Fusarium spp. and competition for food substrate affects the composition and frequency of their occurrence. Mycological researches of the affected barley plants collected in 2012-2014 in the Central region have been showed that the frequency of occurrence of Fusarium spp. selected from roots and ears was ambiguous (Table 3). Out of 208 isolates of fungi classified by the 10 Fusarium species there only $F$. culmorum, $F$. sporotrichioides, $F$. oxysporum, $F$. avenaceum, F. poae were common for the roots and ears of barley. F. sporotrichioides $(48.7 \%)$, $F$. oxysporum $(25.0 \%)$ and $F$. avenaceum $(15.8 \%)$ were dominated on samples isolated from ears. The isolates of $F$. culmorum (22.0\%), F. nivale (15.1\%), F. heterosporum $(16.7 \%)$ have met high frequency on the roots of the barley.

The most adapted pathogenic fungi survive under competitive conditions. Intraspecific variabilities of Fusarium spp. strains to pathogenicity and toxicity have been studied in 2011-2014 by biosample method - germination of wheat seeds (cult. Mironovskaya 808) treated spore suspensions and culture fluids.

There have not been revealed correlation between signs of toxicity and pathogenicity as a result of the comparison of wheat-tester seedlings treated spore suspensions and

\section{Table 4}

The incidence of toxicity and pathogenicity of 212 strains of Fusarium spp. isolated from cereals (on seedlings of the cultivar tester Mironovskaya 808, 2011-2014)

\begin{tabular}{|c|c|c|c|c|c|c|c|c|c|}
\hline \multirow{2}{*}{$\begin{array}{l}\text { Species } \\
\mathrm{NP}^{*}\end{array}$} & & \multicolumn{4}{|c|}{ Pathogenicity, $\%$} & \multicolumn{4}{|c|}{ Toxicity, $\%$} \\
\hline & & $\mathrm{NP} *$ & SP & MP & $P$ & NT & ST & MT & $\mathrm{T}$ \\
\hline Mean for 83 & unit & 32 & 12 & 16 & 23 & 2 & 4 & 12 & 65 \\
\hline $\begin{array}{l}\text { Fusarium strains } \\
\text { isolated from } \\
\text { barley }\end{array}$ & $\%$ & 38.5 & 14.5 & 19.3 & 27.7 & 2.4 & 4.8 & 14.5 & 78.3 \\
\hline Mean for 129 & unit & 37 & 45 & 32 & 15 & 8 & 25 & 51 & 45 \\
\hline $\begin{array}{l}\text { Fusarium strains } \\
\text { isolated from } \\
\text { wheat }\end{array}$ & $\%$ & 28.7 & 34.9 & 24.8 & 11.6 & 6.2 & 19.4 & 39.5 & 34.9 \\
\hline F. sporotrichiodes & & 13.3 & 0 & 33.3 & 53.3 & 0 & 0 & 18.7 & 81.3 \\
\hline F. culmorum & & 0 & 16.7 & 27.8 & 55.6 & 0 & 0 & 44.4 & 55.6 \\
\hline F. sambucinum & & 18.2 & 9.1 & 36.4 & 36.4 & 9.1 & 9.1 & 9.1 & 63.6 \\
\hline F. oxysporum & & 31.6 & 31.6 & 22.8 & 14.0 & 0 & 9.8 & 34.4 & 55.7 \\
\hline F. heterosporum & & 42.9 & 25.0 & 17.9 & 14.3 & 6.4 & 25.8 & 12.9 & 54.8 \\
\hline F. solani & & 66.7 & 22.2 & 11.1 & 0 & 0 & 0 & 55.6 & 44.4 \\
\hline F. graminearum & & 0 & 86.7 & 13.3 & 0 & 6.7 & 6.7 & 6.7 & 80.0 \\
\hline F. avenaceum & & 42.8 & 28.6 & 28.6 & 0 & 0 & 57.1 & 14.3 & 28.6 \\
\hline F. gibbosum & & 12.5 & 37.5 & 37.5 & 12.5 & 0 & 50.0 & 12.5 & 37.5 \\
\hline
\end{tabular}

* NP/NT: non-pathogenic/non-toxic (inhibition of plant growth at 0-30\%), SP/ST: slightly pathogenic/slightly toxic (inhibition at 31-50\%), MP/MT: moderately pathogenic/moderately toxic (inhibition at 51-70\%), P/T: pathogenic/toxic (inhibition of more than 70\%) 
culture fluids of 83 and 129 Fusarium strains isolated from barley and wheat, respectively. More than $50 \%$ of Fusarium strains have been showed low pathogenicity to the wheat-tester (Table 4). The total expression of pathogenic traits on tester seedlings was about the same as for the strains isolated from barley and wheat, and amounted to $47.0 \%$ and $36.4 \%$, respectively. The majority of Fusarium strains had expressed the toxicity to the seedlings of the tester. The toxicity of the strains of fungi isolated from barley was $78.3 \%$ against $34.9 \%$ isolated from wheat. So the strains having high and moderate toxicity have been accounted for $74.4-92.8 \%$.

The strains of the genus Fusarium have been largely varied according to the intensity of the pathogenicity and toxicity. There were noted minor differences in the studied traits of the Fusarium spp. Thus, there were revealed the predominance high pathogenic (from $36.4 \%$ to $55.6 \%$ ) and toxic activity (from $55.6 \%$ to $81.3 \%$ ) for $F$. sporotrichiodes, $F$. culmorum, F. sambucinum strains.

F. oxysporum and F. heterosporum strains have poorly inhibited the growth of seedling-testers treated spore suspensions, and they were mainly non-pathogenic (for 31.6 and $42.9 \%$ ) and slightly pathogenic (25-31.6\%). Moreover some strains of the species stimulated the growth of wheat seedlings by 15-30\%. However, F. oxysporum and F. heterosporum have been showed high toxicity to the testers treated by culture fluids of the strains $(54.8-55.7 \%)$.

Strains of $F$. solani have possessed contrasting properties: non-pathogenic were $66.7 \%$ of the strains, toxic (along with moderately toxic) $-100 \%$.

Isolates of $F$. gibbosum and $F$. avenaceum were characterized by weak to moderate pathogenicity $(87.5-100 \%)$ and relatively low toxicity $(50-57.1 \%)$.

Most strains of $F$. graminearum have showed weak pathogenicity $(86.7 \%)$ and high toxicity to the seedlings of testers $(80 \%)$.

Strains of rare species of genus Fusarium, such as F. redolens, F. verticiloides, F. tricinctum, have produced moderate toxicity to seedlings of the test crops, but proved to be non-pathogenic, which may explain their insignificant component in the microbiota of Root Rot.

\section{Conclusion}

The composition of Fusarium pathogens in cereals was represented by widespread and rare species of these fungi. The results of the monitoring of fungi in stalks and roots of grain crops has been indicated relatively high uniformity of Fusarium spp. in the regions of the Russian Federation due to the susceptibility of crops to the soil-inhabiting micromycetes.

The frequency of occurrence of micromycetes has been stable for the roots and for the ears it has been determined by the weather during the growing season of plants.

The annual occurrence of Fusarium spp. on the ear and grain mainly has been associated with active reproduction of the fungus on the underground parts of plants.

Consistent long-term monitoring of the dynamics and frequency of occurrence of Fusarium spp. in a wide range of climatic areas there has made it possible to characterize 
the state of the species of fungi in the Russian regions and also to study their intraspecific and interspecific variability in toxicity and pathogenicity depending on biotic and abiotic factors.

The prevalence of Fusarium spp. have been determined by their plasticity and viability in the soil, on the weed roots and in the stubble of many crops and high competitive ability in the mycobiota of agriculture expressed pathogenic and toxic activity.

\section{Literature}

Bilai, V. I. (1977): Fusarium. Naukova Dumka, Kiev, 443 p.

Bilai, V. I. (1988): Microorganisms - agents of plant diseases. Sciences Dumka, Kiev, 552 p.

Burgess, L. W. and Griffin, D. M. (1967): Competitive saprophytic colonization of wheat straw. Ann. Appl. Biol. $60,137-142$.

Chulkina, V. A., Toropova, E. Yu. and Stectov, G. Yu. (2009): Integrated pest management: phytosanitary systems and technology. Kolos, Moscow, $670 \mathrm{p}$.

Dudka, I. A. (1982): Methods of experimental mycology. Sciences Dumka, Kiev 550 p.

Gagkaeva, T. Yu., Gavrilov, O. P., Levitin, M. M. and Novozhilov, K. V. (2011): Fusarium of cereals. Supplement to the journal Plant Protection and Quarantine 5, $52 \mathrm{p}$.

Grishanova, A. A. (2014): Magazine Agroprofi Dangerous fungi. www. agro-profi.ru / 2014/06/08 / dangerous fungi/

Ivanov, A. V., Semenov, E. I., Ermolaeva, O. K., Galiev, G. M. and Tremasov, M. J. (2013): Toxigenic potential of Fusarium sporotrichioides strains. Mycology and Plant Pathology Problems of the XXI. Proc. of the International Scientific Conference Devoted to the 150th Anniversary of the Corresponding Member of the Academy of Sciences of the USSR, Professor A. A. Yachevsky. St. Petersburg October 2-4, pp. $142-145$.

Kirichenko, A. A. and Toropova, E. Yu. (2007): Biological substantiation of monitoring, prediction and control of the embryo black spring wheat in Novosibirsk Region. Siberian Agricultural Gazette Science 8, 31-34.

Parfenova, T. A. and Alekseeva, T. P. (1995): The toxic influence of culture filtrate of Fusarium fungi on wheat seeds. Mycology and Phytopathology 29, 78-82.

Parry, D. W., Jenkinson, P. and McLeod, L. (1995): Fusarium ear blight (scab) in small grain cereals - a review. Plant Pathol. 44, 207-238.

Pomeranz, Y., Bechter, D. B., Sauer, D. B. and Seitz, L. M. (1990): Fusarium head blight (scab) in cereal grains. Advance in Science and Technology of Cereals. American Association of Cereal Chemists. St. Paul, pp. $373-433$.

Popov, D. Ju. (2015): The dynamics of the main pathogens and the methods of control of seed infection. Proc. of the International Conference with the elements of scientific school for young scientists and students "Modern systems and methods of examination and management phytosanitary protection of plants." Bolshie Vyazemy, Moscow Region, 24-27 November, pp. 107-112.

Shakhnazarova, V. Yu., Strunnikova, O. K. and Vishnevskaya, N. A. (2004): Progress of populations of Fusarium culmorum in soil: features of formation and lysis of the various structures of the fungus. Mycology and Phytopathology 3, 79-88.

Sorokin, O. D. (2009): Applied statistics on the computer. Krasnoobsk, RPO SUE SB RAAS, 222 p.

Toropova, E. Yu., Chulkina, V. A. and Stectov, G. Y. (2010): Effect of tillage methods on phytosanitary condition of crops. Protection and Plant Quarantine 1, 26-27.

Toropova, E. Yu., Stectov, G. Y. and Chulkina, V. A. (2011): Epiphytotiology. Novosibirsk State Agrarian University, Novosibirsk, $711 \mathrm{p}$.

Toropova, E. Yu., Selyuk, M. P., Yushkevich, L. V. and Zakharov, A. F. (2012): Phytosanitary effects of soil cultivation in forest-steppe of Western Siberia. Bulletin BSAA named by V. R. Filippov. 3, pp. 86-91. 
Toropova, E. Yu., Kazakova, O. A., Vorobeva, I. G. and Selyuk, M. P. (2013): Fusarium root rot of crops in Western Siberia and Ural. Protection and Plant Quarantine 9, 23-26.

Toropova, E. Yu., Kirichenko, A. A., Stetsov, G. Ya. and Suhomlinov, V. Y. (2015): Soil infections of grain crops with the use of the resource-saving technologies in Western Siberia, Russia. Biosciences Biotechnology Research Asia 12, 1081-1093.

Tuterev, S. L. (2005): Treatment the seeds of cereal crops. Protection and Plant Quarantine 3, 44.

Wagacha, J. M. and Muthomi, J. W. (2007): Fusarium culmorum: Infection process, mechanisms of mycotoxin production and their role in pathogenesis in wheat. Crop Protection 26, 877-885. 